\title{
Constraints Experienced by the Piggery Farmers of West Godavari District of Andhra Pradesh
}

\author{
K. Sravan Naga Parimala Kumar* and Syed H. Mazhar
}

Department of Agriculture Extension and communication, Naini Agricultural Institute, Sam

Higginbottom University of Agriculture Technology and Sciences, Prayagraj (Allahabad), India

*Corresponding author

\section{Keywords}

Constraints,

Barriers, Hindrance,

Piggery farming,

Entrepreneur,

Piggery farmers

Article Info

Accepted:

15 September 2020

Available Online:

10 October 2020

\section{A B S T R A C T}

Animal products serves as an alternative source of nutrients and ensures food security while feeding the growing population of India. Among the various livestock species, pigs are one of the fast-growing and efficient feed converters. Simultaneously, piggery farming is one of the most successful commercial business farming and acts as the source of livelihood for the rural poor with lower socio-economic strata. Hence, in order to ensure food security and to promote the livelihood of rural poor, promoting the piggery farming becomes essential. In order to promote, piggery farming, the constraints experienced by them should be eliminated; which requires a detailed study on the constraints. The objective of the study is to analyse the constraints experienced ny the piggery farmers and to provide suggestions to promote piggery farming. The study was conducted at eight blocks of West Godavari district which possess a greater number of piggery farmers. All the 72 piggery farmers were selected as respondents and the primary data was collected from the them with the help of pre-tested structured interview schedule during 2019-2020. The secondary data was gathered from the officials of the state department of animal husbandry. The findings of the study identified the major constraints experienced by the piggery farmers which were lack of government Schemes and policies, lack of organized markets, lack of consumers in the area, less popularity of pork, high cost of concentrate and animal feed.

\section{Introduction}

India has the second highest population in the world. While, animal products play a prominent role in feeding the growing population of India and ensures food security with its nutritional content. Animal products not only act as a source of nutrient but also their wastage acts as a source for manure, fertilizer and paves way for economic diversification and risk distribution. Among different livestock species, one of the most potential source is piggery; as it acts as source for meat production, bristles and manure.

Pigs are referred as prolific and fast-growing species which are more efficient feed converters after the broiler. Pork (Pig's meat) 
is known as alternative source of cheap, high quality dietary protein. Consequently, pig farming is one of the most profitable enterprise as it possesses many economic traits like high prolificacy, faster growth rate, shorter generation interval, low cost of rearing and high dressing percentage with better feed conversion efficiency. Similarly, the pigskin and bristles are used in manufacture of light leather and brushes in Asian countries; pork can be sold for income; processed meat as sausage; pig manure is a manure or fertilizer; while biogas from pig waste helps to produce cooking gas and stimulates the growth of micro-organisms and plants for feeding freshwater fish and ducks.

Marketing of pigs were controlled by middlemen and sold as live. In India, the pig population was around 12.79 Million on 1992 and 13.291 million in 1997 which revealed that pigs constitute around $1.30 \%$ of total world's population. Simultaneously, the total pig population was decreased and currently the population is 9.06 million which $1.7 \%$ of the total livestock population. Meanwhile, Indian share in piggery meat production was also moderately increased from $0.53 \%$ in 1981 to $0.63 \%$ in 2002 .

The contribution of pork products was $0.80 \%$ in total livestock products and $4.32 \%$ of the meat and meat products. Based on the annual report (2012-13) from animal husbandry, the pig population of India constitutes around 11.1 million. According to $18^{\text {th }}$ livestock Census of India (2007), there was a marginal decline in total swine population which indicates pork production in India is limited, representing only $7 \%$ of the country's animal sources. In addition to this, in $20^{\text {th }}$ livestock census of India, the total pig population constitutes around 9.06 million and its growth was declined by $12.03 \%$ in comparison with $19^{\text {th }}$ livestock census.
Studies by Banta et al., (2012) reported that piggery farmers had problems like high cost of feed, high cost of veterinary services, poor housing and low price for pigs in the market, lack of finance, high cost of transportation and lack of improved breeds.

While Mutibvu et al., (2012) identified feed shortage as second most important problem by livestock farmers. Lack of adequate credit facilities, inadequate scientific knowledge on pig farming, lack of veterinary facility, lack of breeding and lack of marketing facilities were regarded as constraints by Nath et al., (2012).

Kambashi (2014) reported that lack of financial support, unavailability of stock and social risk was the major constraints. Consequently, Pegu (2014) revealed that, lack of quality breeding stock, lack of linkage with financial institute, lack of time to reform, outbreak of disease, seasonal fluctuations, lack of training, lack of proper veterinary support, lack of proper marketing channel. Lack of access to extension services, struggle for spot in market place were the most important constraints.

While Patr et.al., (2014) identified that high cost of concentrate feed, non-availability of proper veterinary health care, high cost of initial input and lack of quality piglet, frequent outbreak of diseases, lack of availability of good breeding boar and lack of market linkages.

The prominent constraints which affect pig farmers were wrong timing of extension agent visits, irregular visits, unavailability of needed information (Agbelemoge, et al., 2015). In addition to this, Shadap (2015) found that high cost of concentrate feed, limited medicines and vaccines, inadequate input supply from government, economic problem were the major constraints. 


\section{Statement of the problem}

The lowest socio-economic strata people in India depend on pig farming for their livelihood and they were unaware of the scientific pig farming techniques. Hence, to improve the livelihood the rural poor and to increase the pork production and export, improvising and promoting schemes to popularise the scientific pig breeding cum rearing. Therefore, with reference to importance of pig farming and its contribution to rural poor, it become necessary to promote pig farming in India which can be done through a detailed analysis on the constraints experienced by the piggery enterprises and eliminating them. In the light of the context, the objectives of the study were framed.

1. To study the constraints experienced by the piggery entrepreneurs

2. To provide suggestions to overcome the constraints experienced by the piggery entrepreneurs.

\section{Materials and Methods}

The present study was carried out in West Godavari district of Andhra Pradesh. Being the researcher's native, West Godavari district is selected purposively. Out of forty-eight blocks, the eight blocks which possessed a maximum number of piggery farmers were selected. The selected blocks were Pedavegi, Chintalpudi, Bhimadole, Pedapadu, Eluru, Bhimavaram, Denduluru and Tadepalligudem. The list of piggery farmers was gathered from the officials of the State department of Animal Husbandry. From which, all the seventy-two piggery farmers were selected as respondents. The primary data was gathered from the respondents with the help of a structure interview schedule during 2019-2020. The data gathered from the respondents were tabulated and analysed.

\section{Results and Discussion}

The constraints experienced by the piggery farmers were gathered, tabulated, analysed and the results are presented.

It can be seen from the table 1 , that all piggery farmers $(100 \%)$ reported lack of government schemes and policies as their most important constraint and secured first rank among the other constraints. Simultaneously, the other constraints enlisted by the piggery farmers were, lack of organized markets $(98.6 \%)$, lack of consumers $(97.2 \%)$, less popularity of pork (94.4\%), high cost of concentrated and animal feed $(93.5 \%)$, poor rapport with extension agencies $(77.7 \%)$, lack of veterinary services $(68.5 \%)$, lower productivity of animals (65\%), higher cost of veterinary services $(40.2 \%)$.

These results are in harmony with findings of Chandrashekhar (2007) and Vijay et al., (2012), Banta et al., 2012), Mutibvu et al., (2012), Nath et al., (2012), Kambashi (2014), Pegu (2014), Patr et al., (2014), Agbelemoge et al., (2015), Shadap (2015).

\section{Suggestions to overcome the constraints experienced by the piggery farmers}

For proper knowledge regarding pig rearing, short term and long-term training programs need to be organized in village and block level then proper follow up of selected trained farmers.

Proper veterinary care at farm level to decrease the mortality rate.

Proper irrigation facilities for fodder production and proper utilization of kitchen and house waste.

Additional care of pregnant sows through locally prepared nutritional supplements and routine checkups could ensure vet care for better caring 
of piglets and increase litter size.

Due to high productivity of small pork, processing unit is required in the village

Training for value addition for the farmers and retailers of pig is required.

Farmers can get double output in a short period of time if proper management has been done.

Piggery should be commercialized in rural areas along with advancement in technology transfer.

Future marketing is bright in this field due to high income.

The performance in growth of T\&D breed pigs was tremendous, having low mortality rate, high weight gaining capacity and most important birth giving capacity of sows' Hence there is a need to motivate farmers to shift from traditional (local pig) to "T\&D" pig (crossbred).

Develop a comprehensive community based Vet Care System through capacity building of local youth or SHG members as Para vets or Animal Health Workers. They should be able to carry out routine vaccination of fatal diseases, de-worming and mobilizing the community to adopt better animal, feed, watershed hygiene, reduce overcrowding, isolation of sick animals as prevention measures through innovative behavior.

Table.1 Distribution of constraints faced by the piggery farmers $(n=72) *$

\begin{tabular}{|l|l|c|c|c|}
\hline S. No & \multicolumn{1}{|c|}{ Constraints } & Number* & Percentage & Rank \\
\hline 1. & Lack of government schemes and policies & 72 & $100 \%$ & I \\
\hline 2. & Lack of organized markets & 71 & $98.6 \%$ & II \\
\hline 3. & Lack of consumers in the area & 70 & $97.2 \%$ & III \\
\hline 4. & Less popularity of pork & 68 & $94.4 \%$ & IV \\
\hline 5. & High cost of concentrates and animal feed & 65 & $93.5 \%$ & V \\
\hline 6. & Inadequate bank loans & 61 & $84.7 \%$ & VI \\
\hline 7. & Lower productivity of animals & 56 & $77.7 \%$ & VIII \\
\hline 8. & Poor rapport with extension agencies & 49 & $68.5 \%$ & IX \\
\hline 9. & Lack of veterinary services & 29 & $40.2 \%$ & X \\
\hline 10. & $\begin{array}{l}\text { Higher cost of veterinary services and } \\
\text { medicines }\end{array}$ & & & \\
\hline
\end{tabular}

*-Multiple responses

In conclusion the commercial pig farming is one of the most successful business in India. Though, initial investment in pig farming seems to be high, the return from investment will be quicker. The faster growth rate, efficient feed conversion makes pig farming profitable and easier. Though, it is easier, it involves some constraints like faster disease transmission, lack of veterinary hospitals and limited medicines which lead to death of pigs and loss in venture. Essential care should be taken in nursery for housing, feeding and waste management. Necessary plans and schemes should be devised by the animal husbandry department to promote pig farming. Simultaneously, awareness campaigns should be conducted to improve the knowledge on scientific farming among piggery farmers. 


\section{References}

Agbelemoge, A. and Akinwumi, D.M. (2015). Utilization of Extension Information among pig Farmers in Oke - aro Farm Settlement in Ogun State of Nigeria. American Journal of Humanities and Social Sciences, 3(1), 1 - 6.

Banta, A.L., Wamagi T.I., Ayuba A.M. and Olukosi J.O. (2012): Analysis of socio economic characteristics of pig farmers that influence sustainable development in Kaduna state, Nigeria. Journal of Agriculture and Veterinary Sciences, 4.

Mutibvu, T., Maburutse, B.E., Mbiriri, D.T and Kashangura, M.T. (2012). Constraints and opportunities for increased livestock production in communal areas: A case study of Simbe, Zimbabwe. Department of Animal Science, University of Zimbabwe. Nishi,

Pegu (2014): Piggery Enterpreneurship in Dhemaji district of Assam. Thesis; College of Veterinary Science, Assam Agricultural University, Guwahati, Assam, India

Shadap (2015): Government sponsored piggery development in Meghalaya. M.V.Sc.

Thesis, College of Veterinary Science, Assam Agricultural University, Guwahati, Assam, India.

\section{How to cite this article:}

Sravan Naga Parimala Kumar, K. and Syed H. Mazhar. 2020. Constraints Experienced by the Piggery Farmers of West Godavari District of Andhra Pradesh. Int.J.Curr.Microbiol.App.Sci. 9(10): 1989-1993. doi: https://doi.org/10.20546/ijcmas.2020.910.242 